\title{
Local Governance Reforms in Zambia: A Review
}

\section{Bornwell Chikulo}

NorthWest University, South Africa

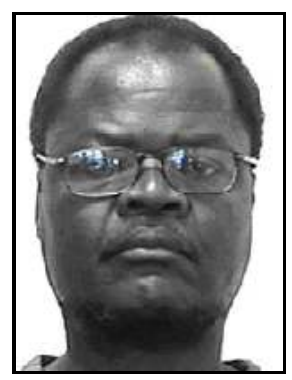

\section{Introduction}

This paper provides an overview of the efforts of successive Zambian governments to transform and institutionalise democratic local governance, and to come to grips with the socio-economic development challenges facing the country. It assesses the progress and challenges that governments are facing in their efforts to transform local government into democratic, developmental local governance.

Local governance reform has been transforming the structure of governance in Zambia. Since the country attained political independence from Britain in 1964, a commitment to decentralisation and popular participation has been an important component of local governance reform strategies. The problem that confronted the government at independence was one of transforming the inherited provincial and district government structures into a dynamic local governance framework that could facilitate sustainable public participation in the socio-economic development strategies envisaged by the new regime. The officially stated policy has been one of "taking power to the people" (Zambia, 1972:33), and a critical objective of the local governance reforms has been to strengthen local authorities by the decentralisation of power. Consequently, over the years governments have sought to design and implement decentralised democratic local governance to facilitate wider participation by the citizenry and facilitate effective service delivery. 


\section{Local Governance Reforms}

This section provides an overview of the reforms implemented in four phases between 1964 and 2008.

\section{Phase I: 1964-1970}

The initial phase entailed the new government's attempts to establish political control and transform the inherited provincial and district government structures into cohesive, dynamic organisations of local development management, which could facilitate sustainable socio-economic development (Chikulo, 1981, 1985a).

On gaining independence in October 1964, Zambia inherited a dual system of administration. This comprised central government field administration and elected local government. Zambia was divided into eight provinces consisting of 44 districts. At the sub-district level there were Native Authorities in the rural areas. 1965 saw the abolition of Native Authorities, which were viewed as symbols of colonial repression and manipulation, and the introduction of new local governments under the Local Government Act (No.30) of 1965. Under this Act, 67 local authorities were established: 24 were urban authorities, and 43 were rural councils. The Act gave local authorities wide-ranging powers to discharge over sixty functions in their areas of jurisdiction.

In November 1968, the government announced reforms which entailed 'decentralization in centralism'. As the then President Kaunda (1968:19) elaborated:

"I define this decentralization in centralism as a measure whereby through the Party and Government machinery, we will decentralize most of your Party and Government activities. While retaining effective control of the party and Government machinery at the centre in the interests of unity."

At the district level, these reforms involved the appointment of a District Governor (DG) to head each of the 53 districts. The DG became the politico-administrative head of the district. He was the personal representative - alter ego - of the President, and performed this role through the various committees he chaired in the district. Thus during this phase the government sought to institute political control over field administration, hence the emphasis on cohesion and the need to build a centralized polity (Chikulo, 1981).

\section{Phase II: 1971-1979}

The second phase involved efforts by the government to create a network of 'grassroots participatory' structures between the local authorities and the subdistrict level in order to facilitate public participation (Zambia, 1971). The abolition of Native Authorities had created an institutional gap between the local authorities and the sub-district level. In order to plug this gap village productivity committees, 
ward councils and ward development committees were established under the Village Registration and Development Act (No. 30) of 1971. This made the village the primary focus at district level. Under the provisions of the Act, a village productivity committee (VPC) was established in each village, sitting under the chairmanship of the village headman. The VPC was responsible for considering the administrative and development needs of the community and sending representatives to the ward development committees (WDCs). A WDC was established in every local government ward - a ward being an area within a local authority from which a councillor is elected under the provisions of the 1965 Local Government Act. The functions of WDCs were to consider development needs, get ideas from VPCs, and pass these on to the local authority. This network of committees was supposed to provide the basis for decentralized local governance.

\section{Phase III: 1980-1990}

On $13^{\text {th }}$ December 1972 Zambia was formally proclaimed a 'One-Party Participatory Democracy', thereby granting the ruling party constitutional paramountcy over the entire state administrative apparatus. As then President Kaunda (1973) aptly put it:

"The Party is supreme in our One-Party Participatory Democracy. It is the source of national policy. The Party will not only be interested in working out broad policies and objectives, it will be directly involved in the planning, organization, control and management of the entire administrative machinery of our nation".

This phase witnessed increased politicisation and the imposition of the supremacy of the party over local governance (Chikulo, 1985b, 1989). Consequently, the central and local government administration was merged with the ruling party (UNIP) structures, to create an integrated district administration, under the 1980 Local Administration Act (No.15). The major objective of the 1980 Act was to "...ensure the effective integration of the primary organs of the party and other local administration units in the district."

The most significant structural change entailed in the 1980 Act was the abolition of the distinction between party, central and local governments. This involved the establishment of an administrative structure composed of party, central and local government officials. The stated goal of the reforms was to integrate local administrative departments of the central government, local councils, and the party structure in order to improve coordination and eliminate duplication among them. Consequently, a single integrated politico-administrative structure was created in each of the fifty-five districts, to which was assigned the totality of party, central and local government activity. A single administrative agency called the district council was established in each district under the chairmanship of a centrallyappointed political appointee - the District Governor. The council was a statutory, deliberative, and consultative body, concerned with the determination of broad policy objectives and critical assessment of development programmes. 
The new councils went beyond what Leemans (1970:53) called 'a single hierarchy model' of government at district level, since they replaced the former tripartite local government framework, including the incorporation of the party organization into the new structure. As a consequence, the new structure of local government not only brought the decision-making process closer to the public at district level, but also ensured closer party control over the mechanism of field administration. Thus political control was considered crucial for the effective functioning of the new system of local administration.

At the sub-district level, the 1980 reforms were designed to reinvigorate the administrative structures by eliminating the duplication of work between party committees and local government committees. Consequently, the party organizations from constituency to section level were merged with ward development committees and village productivity committees into a single set of structures vertically integrated with the district council. These performed both the functions assigned to the party committees by the UNIP Constitution, and the functions assigned by the 1971 Village Registration and Development Act. The single hierarchy of committees consisted of ward, branch and section committees. Local government elections were abolished and replaced with party elections. Party officials elected as ward chairmen, represented the ward on the council. The 1980 Act increased the representation of local party members and excluded the majority of local residents who were not members. As a consequence, democratic local governance was undermined at the local level, as the party representatives were not elected by universal adult suffrage, yet they were expected to represent and take decisions on behalf of local communities.

The system of local governance established by the 1980 reforms was, therefore, basically an attempt to create an institutional synthesis between local government, central government, and the party. It thus approximated what Coleman and Rosberg (1964) called a 'party-state', in which, in order to achieve higher levels of mobilization for socio-economic development, the distinction between civil servant and politician was blurred and the relationship between them transformed.

\section{Phase IV: 1991- 2008}

A clamour for multi-party democracy led to the scrapping of the de jure one-party state in December 1990, and the introduction of political pluralism (Chikulo, 1996). Consequently, the transition to a multi-party system demanded a restructuring of local government. Firstly, local government had to be 'de-linked' from the ruling party; and secondly, measures were introduced to strengthen democratic control over administration, and increase its accountability to democratically elected bodies. The promulgation in August 1991 of the Constitution of Zambia Act (No.1) and the Local Government Act (No.22), 'delinked' the ruling party from all civil service and state apparatus, repealed the 1980 Local Administration Act (No.15), and re-introduced the distinction between the ruling party, the central government, and local government. 
In addition, the 1991 Local Government Elections Act (No.26) re-introduced universal adult suffrage at the local government level. This democratised local government by affording every citizen who is a registered voter an opportunity to stand for election, or vote for the candidate of his choice, irrespective of political affiliation. The Act provides for the demarcation of the council's area of jurisdiction into wards from which councillors are elected for a five-year term.

\section{Current Structure of Local Governance}

The current system of local government in Zambia flows from the fourth phase of reforms. The Constitution of Zambia provides for the establishment of a democratically elected local government system based on universal suffrage, whilst the 1991 Local Government Act provides for a single-tier system of local government comprising three types of councils: city, municipal and district.

There are 72 local authorities countrywide:

- 4 are designated as City Councils

- 12 are Municipal Councils

- 56 are District Councils (comprised of smaller rural-based local authorities).

The composition of councils is as follows:

- All elected councillors in the district

- All members of parliament in the district

- Two representatives appointed by all chiefs in the district - as a means of involving traditional rulers in local governance.

The 1991 Local Government Act provides for the establishment of a Local Government Electoral Commission to administer local government elections. Councillors are elected every five years. Initially, this was only three years, but the Local Government (Amendment) Act (No.8) of 2004 provided for a change of tenure to five years, in order to align it with presidential and parliamentary elections.

Councillors elect mayors and deputy mayors every year in the city and municipal councils, and chairmen and deputy chairmen in district councils, from amongst themselves. Members of parliament and chiefs' representatives are not eligible for these positions. The mayor/chairperson is the political head of the council and performs ceremonial functions, but lacks executive powers. The town clerk or district secretary is the executive head of the council.

The Local Government Act of 1991 (as amended several times) empowers all categories of local authorities to undertake wide-ranging functions. The councils are recognised as the primary bodies responsible for development at district level. They are the statutory deliberative and consultative bodies concerned with the 
determination of broad policy objectives and critical assessment of development programmes, as well as the efficient and effective management of their areas. Consequently, the Act gives sixty-three scheduled functions to the councils, which include among others the provision of services such as water supply, sewerage, health, feeder and district roads, education and housing. Thus the 1991 Act has strengthened the role of councils as focal points for wider participation and delivery of social services to the local communities.

With regard to finance, the Act gave councils powers to raise and utilize revenue from their own local sources at their discretion. In addition, councils receive transfers of funds from central government, which are supposed to be their major source of revenue. The transfers are firstly, the means by which the central government shares taxes with councils; and secondly, provide a conduit through which various grants from sector ministries are disbursed to enable councils to undertake delegated functions on their behalf. These grants take various forms consisting of general, special and capital grants. Special grants are meant for financing projects which are prior-earmarked by central government. Capital grants are meant to be used for financing capital projects, while general grants are additional financial resources extended to district councils.

\section{Key Challenges to Effective Local Governance}

Legal, policy and institutional frameworks have been put in place to establish and democratise local governments, with the objective of deepening democracy and improving service delivery. However, there are three key challenges affecting the effectiveness of local governance (Chikulo, 2000; Zambia, 2002a and b).

\section{Financial Crisis}

Raising sufficient revenue is one of the most intractable problems facing most local authorities, and the majority of councils are unable to meet their statutory functions and obligations. Although the 1991 Local Government Act has given councils vast powers to raise and generate their own revenues, few are able to take advantage of this provision due the fact that their resource base is too small to sustain their operations. As a result, local authorities have accumulated crushing burdens of debt or arrears and are now faced with financial crises (Crook and Manor, 2001). Few can stand on their own feet.

In addition, government actions and policies have exacerbated the financial problems of councils, which face severe resource constraints due to the following:

- Declining and erratic disbursements of grants from central government

- Erosion of asset base through various actions and policies of the central government such as the 1992 directive to councils to disinvest in commercial ventures and sell rental housing stock at uneconomical prices

- Unfunded mandates - local authorities given increasing responsibilities without corresponding capacity in resource mobilization 
- Redirection of funds intended for local authorities to the control of local politicians, for example constituency development funds and youth projects funds controlled by MPs, or to semi-autonomous local institutions such as the Health and Education Management Boards created to perform specific functions on behalf of sector ministries.

This lack of resources has left significant gaps in service delivery capacity and placed limitations on the extent of to which stakeholders can participate in development management. Without financial sustainability, local authorities are unable to effectively provide services to their communities, and their developmental capacity and autonomy are thereby undermined.

\section{Lack of Integrated District Development Management and Planning}

There is a lack of holistic, integrated planning and management at district level. Effective integrated planning and management is undermined by the absence of an effective coordinating mechanism under the direct control of the council. District Development Coordination Committees (DDCCs) were established in 1993 as forums for planning and implementation of development activities, as well as community participation. They are technical committees mandated to coordinate development activities in the district and prepare development plans for submission to the district council. The DDCC is composed of heads of central government departments and other development agencies represented in the district, as well as the executives of the district councils. Thus, the majority of the members are bureaucrats representing central government departments, and are answerable to their parent ministry, not the local authority. The council has no legal administrative authority over central government line ministries. The deconcentrated sector ministries which provide services within the council's area of jurisdiction, report direct to their parent ministries in the capital city of Lusaka. Thus they remain primarily responsible to their ministerial chain of command. The DDCC is thus rendered ineffective because it has no legal authority to back up its operations, and the council has no control over its operations.

\section{The Extent of Meaningful Citizen Participation in Local Governance}

The major weakness in the current local governance system is the lack of legally constituted local government institutions at the local, ward or area level. There is no forum for community participation in decision-making on local development activities and affairs. Under the 1991 Local Government Act, each council's area of jurisdiction is demarcated into wards. However, these wards at the sub-district level are only recognized for purposes of local government elections. As noted earlier, under the previous system of local government, a network of village productivity committees, ward councils and ward development committees had been established to facilitate development and induce participation. These 'grassroots participatory structures' made the local council the primary focus of development at district level. However, under the 1991 Act ward development committees and village productivity committees are not formally linked to local authorities and are thus no 
longer functional in most instances. The result has been the creation of an 'institutional vacuum', with no effective forum for community participation in decision-making on local development activities and issues at sub-district level. Thus although local authorities are accountable to the ratepayers, opinion polls indicate that most people feel councillors do not reflect their views in the council and are not accountable to residents (Moomba, 2002:29; Lolojih, 2003:16). Studies have also shown that the public have little trust in local government and there is a low level of participation in local government elections (Erdmann and Simutanyi, 2003).

\section{Conclusion}

Although local governance reforms have brought about significant changes in policy frameworks and institutional structures, in order to facilitate and anchor effective delivery of socio-economic development services, local authorities are faced with difficult constraints and challenges. The strength of decentralised local governance remains limited. For it to be effective, not only should local governance be downwardly accountable, but other central government agencies and bodies at district level should also be accountable to local government. The argument that democratic decentralised local governance can deliver services more efficiently and more responsively depends on the adequate provision of resources. Yet lack of financial resources continues to constrain the effectiveness of local authorities. The failure to fully empower local authorities undermines their effectiveness and legitimacy.

\section{References}

Chikulo, B.C. 1981. 'The Zambian Administrative Reforms: An Alternative View', Public Administration and Development, vol. 1(1), pp. 55-65.

Chikulo, B.C. 1985a. 'Decentralization in Centralism: An Analysis of the Zambian Experience, 1964-1984', in M. Ndulo and K. Oseihwedie (eds), Issues in Zambian Development, Omenan Press, Roxbury.

Chikulo, B.C. 1985b. 'Reorganization for Local Administration in Zambia: An Analysis of the Local Administration Act, 1980', Public Administration and Development, vol. 5(1), pp. 73-81.

Chikulo, B.C. 1989. 'The Zambian Local Administration Act, 1980: Problems of Implementation', Planning and Administration, vol. 16(1), pp. 62-67.

Chikulo, B.C. 1996. 'Local Government in the Third Republic', in O. Sichone and B.C. Chikulo (eds), Democracy in Zambia: Challenges for the Third Republic, SAPES Books, Harare.

Chikulo, B.C. 2000. 'Decentralization for Good Governance and Development: The Zambian Experience', Regional Development Dialogue, vol. 21(1), pp. 26-48.

Crook, R. and J. Manor, 2001. Local Governance and Decentralization in Zambia, Final Report to SNV, The Ministry of Local Government and Housing and the Donor Reference Group, Lusaka.

Erdmann, G. and N. Simutanyi, 2003. Transition in Zambia: The Hybridization of the Third Republic, Konrad-Adenauer-Stiftung, Lilongwe. 
Government of Zambia, 1971. Village Productivity and Ward Development Committees, Government Printer, Lusaka.

Government of Zambia, 1972. Humanism in Zambia: and A Guide to its Implementation, Parts I and II, Government Printer, Lusaka.

Government of Zambia, 2002a. The National Decentralisation Policy: Towards Empowering the People, Government Printer, Lusaka.

Government of Zambia, 2002b. Africa Governance Forum V: Local Governance and Poverty Reduction: Zambia Country Paper, Government Printer, Lusaka.

Kaunda, K.D. 1968. Zambia's Guidelines for the Next Decade, Government Printer, Lusaka.

Kaunda, K.D. 1973. Speech to the UNIP National Council, Lusaka (mimeo).

Coleman, J.S. and C. Rosberg (eds), 1964. Political Parties and National Integration in Tropical Africa, University of California press, Berkeley.

Leemans, A.F. 1970. New Patterns of Local Government, IULA, The Hague.

Lolojih, P.K. 2003. Report on making Local Authorities more Effective, Transparent and Accountable: An Analysis of Opinion Polls, Public Radio and Television discussions, TI-Zambia, Lusaka.

Momba, J.C. 2002. Report on Problems of Effectiveness in Service Delivery, Accountability and Transparency of Local Authorities in Zambia, TI-Zambia, Lusaka.

Sichone, O. and B.C. Chikulo, 1996. Democracy in Zambia: Challenges for the Third Republic, Sapes Books, Harare. 